\title{
Differences Between Participant and Non-participant Hospitals in the Pennsylvania Rural Health Model
}

J Gen Intern Med 36(9):2891-3

DOI: $10.1007 / \mathrm{s} 11606-020-06551-1$

(C) Society of General Internal Medicine 2021

\section{INTRODUCTION}

Rural hospitals' financial insecurity jeopardizes essential medical services. ${ }^{1,2}$ To provide financial stability and improve rural population health, the Center for Medicare and Medicaid Innovation (CMMI) and Pennsylvania launched the Pennsylvania Rural Health Model (PARHM), an innovative global budget model, beginning in 2019. ${ }^{1}$ Hospitals receive annual risk-adjusted global payments, but must create a plan for shifting from a volume-based to a value-based model.

While Maryland previously implemented a rural hospital global budget model (before expanding to all hospitals), ${ }^{3}$ Maryland had established inpatient rate setting and required all rural hospitals to participate. Similar to most states, Pennsylvania does not have rate setting ability so eligible hospitals could elect to participate in the PARHM. Given the requirements and novelty, hospitals may have opted to delay participation as they developed transformation plans and observed experiences of first year hospitals. As a result, our study aims to estimate the extent to which participating hospitals differed from eligible, but nonparticipating ones, which is important for future evaluations as well as design of other rural-based global budget models.

\section{METHODS}

Eligible hospitals were located in counties designated as rural by the Center for Rural Pennsylvania. ${ }^{4}$ We categorized hospitals as PARHM Year 1 (i.e., joined first year of PARHM), PARHM Year 2 (i.e., joined second year of PARHM), and eligible but non-participating hospitals. We compared three sets of measures between participating and non-participating hospitals: demographics within each hospital's county (from 2018 American Community Survey data), hospital capacity and volume (from 2018 Pennsylvania Hospital Reports ${ }^{5}$ ), and hospital financial outcomes (from 2016 to 2018 Pennsylvania Health Care

Received June 2, 2020

Accepted December 22, 2020

Published online January 26, 2021
Cost Containment Council (PHC4) Financial Analysis Reports). Financial outcomes included the following: net patient revenue, total operating revenue, total margin [(total revenue - total expenses)/total revenue], operating margin [(total operating revenue - total operating expenses)/ total operating revenue], uncompensated care share, and Medical Assistance share. ${ }^{6}$ Total operating revenue includes both net patient revenue and revenue from other operations such as pharmacy, meals, and parking.

We focused on years prior to the PARHM to compare differences between hospitals prior to their potential participation. For each outcome, we compared mean characteristics between PARHM Year 1, PARHM Year 2, and eligible but non-participating hospitals. To test for statistically significant differences (defined as $P<0.05$ ), we estimated $t$ tests for continuous variables and chi-squared tests for categorical variables.

\section{RESULTS}

We found similar county characteristics across all hospitals (Table 1), with the exception of significantly higher unemployment in PARHM Year 1 hospital counties compared to PARHM Year 2 hospitals $(6.4 \%$ vs. $5.3 \%, P=0.045)$. Although none of the differences were statistically significant, PARHM Year 1 hospitals had lower capacity, fewer employees, and lower volume than PARHM Year 2 and nonparticipating hospitals (Table 1). All participating PARHM were non-profit and non-teaching hospitals, except Washington Hospital.

Financially, compared to non-participating hospitals, PARHM Year 1 hospitals had significantly higher uncompensated care rates $(4.0 \%$ vs. $2.2 \%$ of net patient revenue, $P<$ $0.01)$. Although not statistically significant, PARHM Year 1 hospitals had lower net patient revenue ( $\$ 33.2$ million vs. $\$ 116.7$ million), lower operating revenue (\$35.8 million vs. $\$ 114.2$ million), lower total margin (-7.6\% vs. $2.6 \%)$, and lower operating margin $(-9.6 \%$ vs. $1.2 \%)$ than nonparticipating hospitals (Table 1 and Fig. 1). PARHM Year 2 fell between PARHM Year 1 and non-participating hospitals in terms of capacity, volume, and financial performance. Compared to PARHM Year 1 hospitals, PARHM Year 2 hospitals had significantly higher total margins $(0.5 \%$ vs. $7.6 \%, P<0.05)$ and higher operating margins $(-2.4 \%$ vs. $9.6 \%, P<0.05)$. 
Table 1 Comparison of County Demographics and Hospital Characteristics Between Pennsylvania RHM by Participation Status

\begin{tabular}{|c|c|c|c|c|c|c|}
\hline & \multirow{2}{*}{$\begin{array}{l}\text { Non-participating } \\
\text { hospitals }(n=52)\end{array}$} & \multirow{2}{*}{$\begin{array}{l}\text { PARHM } \\
\text { hospitals join } \\
\text { Year } 1(n=5)\end{array}$} & \multirow{2}{*}{$\begin{array}{l}P \text { value } \\
\text { Year } 1 \text { vs. non- } \\
\text { participating }\end{array}$} & \multirow{2}{*}{$\begin{array}{l}\text { PARHM } \\
\text { hospitals join } \\
\text { Year } 2(n=8)\end{array}$} & \multirow{2}{*}{$\begin{array}{l}P \text { value } \\
\text { Year } 2 \text { vs. non- } \\
\text { participating }\end{array}$} & \multirow{2}{*}{$\begin{array}{l}P \text { value } \\
\text { Year } 1 \\
\text { vs. Year } \\
2\end{array}$} \\
\hline & & & & & & \\
\hline \multicolumn{7}{|l|}{ County demographics } \\
\hline Age 65 or older, $\%$ & 19.6 & 20.9 & 0.115 & 19.6 & 0.975 & 0.222 \\
\hline $\begin{array}{l}\text { Population density, } \\
\text { residents/square mile }\end{array}$ & 410.9 & 132.0 & 0.235 & 692.2 & 0.166 & 0.073 \\
\hline \multicolumn{7}{|l|}{ Race/ethnicity } \\
\hline White, $\%$ & 93.8 & 94.9 & 0.568 & 94.3 & 0.731 & 0.751 \\
\hline Black, \% & 2.8 & 2.6 & 0.855 & 2.7 & 0.877 & 0.948 \\
\hline $\begin{array}{l}\text { Bachelor's degree or } \\
\text { more, } \%\end{array}$ & 21.5 & 18.1 & 0.280 & 22.4 & 0.723 & 0.325 \\
\hline Unemployed, \% & 5.6 & 6.4 & 0.161 & 5.3 & 0.499 & 0.045 \\
\hline $\begin{array}{l}\text { Median household } \\
\text { income, } \$\end{array}$ & 51,970 & 51,040 & 0.752 & 54,820 & 0.284 & 0.436 \\
\hline Uninsured, \% & 6.4 & 6.2 & 0.883 & 6.0 & 0.669 & 0.897 \\
\hline \multicolumn{7}{|l|}{ Hospital type } \\
\hline Teaching hospital, \% & 26.9 & 0.0 & $0.171^{*}$ & 12.5 & $0.353^{\mathrm{a}}$ & $0.411^{*}$ \\
\hline Non-profit hospital, \% & 84.6 & 100.0 & $0.344 *$ & 100.0 & $0.233^{\mathrm{a}}$ & - \\
\hline \multicolumn{7}{|l|}{ Hospital capacity } \\
\hline Licensed beds & 125 & 40 & 0.077 & 97 & 0.482 & 0.216 \\
\hline $\begin{array}{l}\text { Total FT employees } \\
\text { (payroll) }\end{array}$ & 623 & 222 & 0.127 & 511 & 0.599 & 0.188 \\
\hline Total operating rooms & 7.1 & 2.8 & 0.064 & 5.5 & 0.386 & 0.142 \\
\hline \multicolumn{7}{|l|}{ Hospital volume } \\
\hline Admissions & 4729 & 1183 & 0.112 & 3757 & 0.613 & 0.161 \\
\hline Average length of stay & 4.6 & 3.7 & 0.115 & 4.0 & 0.210 & 0.645 \\
\hline Occupancy rate & 45.0 & 31.7 & 0.108 & 38.2 & 0.343 & 0.409 \\
\hline $\begin{array}{l}\text { Total surgical } \\
\text { operations }\end{array}$ & 5454 & 1339 & 0.066 & 3848 & 0.366 & 0.052 \\
\hline \multicolumn{7}{|c|}{ Hospital financial outcomes } \\
\hline $\begin{array}{l}\text { Net patient revenue } \\
\text { (\$ millions) }\end{array}$ & 116.7 & 33.2 & 0.111 & 76.1 & 0.334 & 0.230 \\
\hline $\begin{array}{l}\text { Total operating } \\
\text { revenue }{ }^{\ddagger} \text { (\$ millions) }\end{array}$ & 114.2 & 35.8 & 0.107 & 81.0 & 0.408 & 0.214 \\
\hline Total margin $\$, \%$ & 2.6 & -7.6 & 0.086 & 0.5 & 0.653 & 0.035 \\
\hline Operating margin", $\%$ & $\begin{array}{l}2.0 \\
1.2\end{array}$ & -9.6 & 0.051 & -2.4 & 0.405 & 0.045 \\
\hline Uncompensated care ${ }^{\mathbb{I}}$ & 2.2 & 4.0 & 0.001 & 2.4 & 0.610 & 0.101 \\
\hline$\%$ & & & & & & \\
\hline $\begin{array}{l}\text { Medical Assistance } \\
\text { share }, \%\end{array}$ & 12.3 & 11.8 & 0.911 & 14.4 & 0.526 & 0.460 \\
\hline
\end{tabular}

*Chi-square test

tThe revenue hospitals received for patient care only and does not include revenue from other operations

$\ddagger$ All revenues allocated by the hospital to meet operating expenses, including revenue sources such as net patient revenue, investment income, contributions, and revenue from other operations

${ }^{\S}$ The ratio of total income to total revenue

"The ratio of operating income to total operating revenue

"Percent of uncompensated care (charity care and bad debt) relative to net patient revenue

${ }^{\#}$ Percent of Medical Assistance relative to net patient revenue

\section{DISCUSSION}

Not surprisingly, we found that hospitals that chose to participate in the PARHM were smaller, had lower patient volumes, and were more financially strained (including lower operating margins and higher uncompensated care rates) than eligible but non-participating hospitals. While our study is limited to hospitals participating in the first 2 years of the PARHM, this has important implications for other states contemplating similar models. Furthermore, these differences between partici- pating and non-participating hospitals mean future PARHM evaluations will need to account for the observed selection in participation. As the PARHM continues, it will be important to determine whether the pattern of smaller, more financially strained hospitals participating continues and approaches to recruiting additional hospitals may need to account for the different motivations and needs of larger, solid financial performance hospitals. 


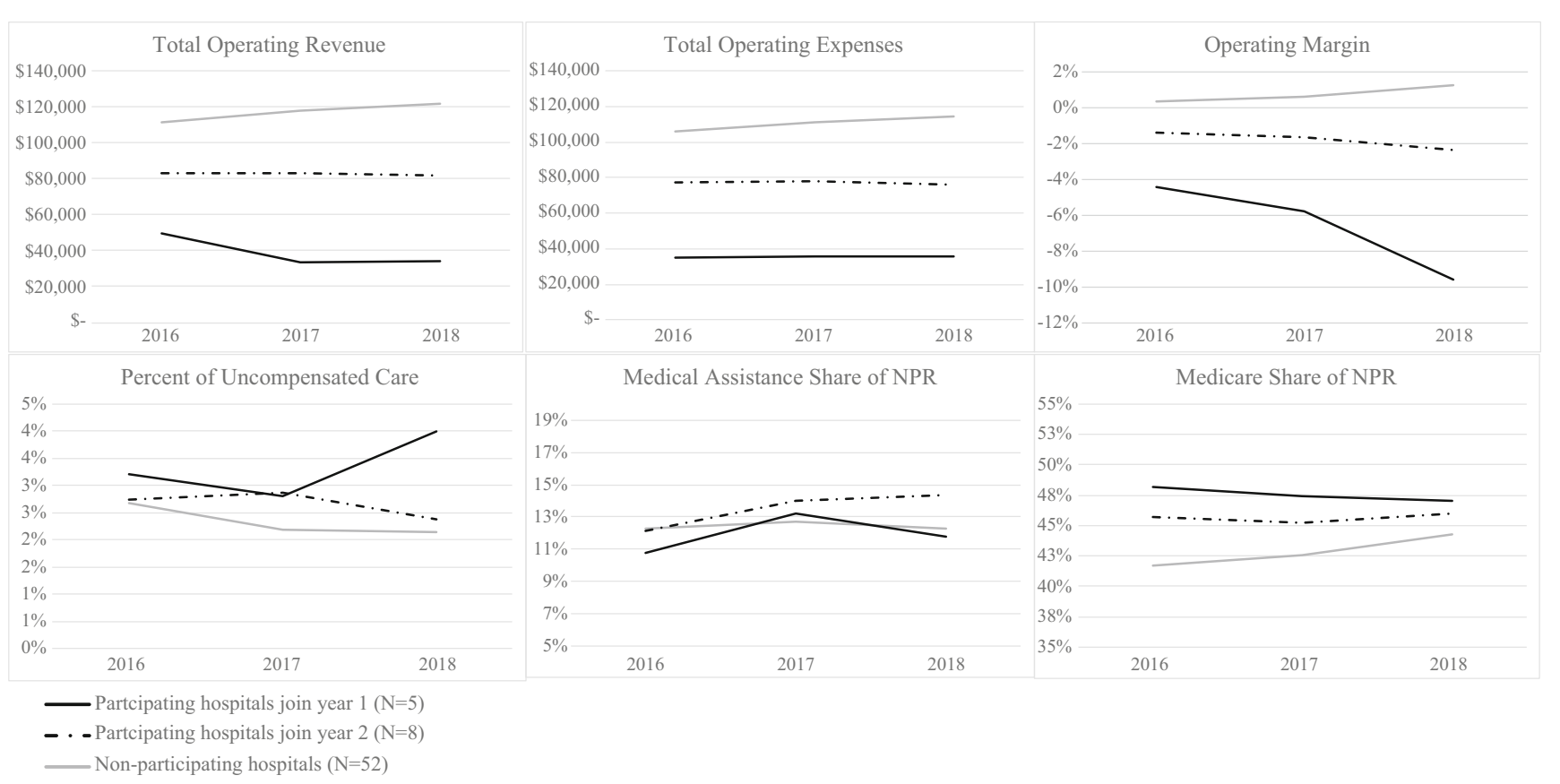

Figure 1 Hospital Financial Characteristics between Pennsylvania RHM by Participation Status, 2016-2018. NPR, net patient revenue. Source: PHC4 Financial Analysis Fiscal Year 2016-2018.

Joel E. Segel, $P h D^{1,2,3}$

Linh Tran, $B A^{1}$

${ }^{1}$ Department of Health Policy and Administration, Pennsylvania State University,

University Park, PA, USA

${ }^{2}$ Penn State Cancer Institute,

Hershey, PA, USA

${ }^{3}$ Department of Public Health Sciences, Penn State College of Medicine,

Hershey, PA, USA

Corresponding Author: Joel E. Segel, PhD; Department of Health Policy and Administration, Pennsylvania State University, University Park, PA, USA (e-mail: jesegel@psu.edu).

\section{Compliance with Ethical Standards:}

Conflict of Interest: Dr. Segel and Ms. Tran received funding from the Commonwealth of Pennsylvania's Department of Health as part of a technical assistance grant for the Pennsylvania Rural Health Model. In addition, Dr. Segel reports that he is currently receiving funding from the Center for Medicare and Medicaid Innovation (CMMI) under a subcontract from NORC as part of an evaluation of the Pennsylvania
Rural Health Model. Neither funder had any role in the design, analysis, or interpretation of the data; nor did they help prepare or approve the manuscript for submission.

\section{REFERENCES}

1. Murphy KM, Hughes LS, Conway P. A Path to Sustain Rural Hospitals. JAMA. 2018;319(12):1193-1194.

2. Kozhimannil KB, Hung $\mathbf{P}$, Henning-Smith C, Casey MM, Prasad $\mathbf{S}$. Association Between Loss of Hospital-Based Obstetric Services and Birth Outcomes in Rural Counties in the United States. JAMA. 2018;319(12):1239-1247.

3. Roberts ET, Hatfield LA, McWilliams JM, et al. Changes in Hospital Utilization Three Years into Maryland's Global Budget Program for Rural Hospitals. Health Affairs (Project Hope). 2018;37(4):644-653.

4. The Center for Rural Pennsylvania. Rural Pennsylvania Counties. 2014; https://www.rural.palegislature.us/demographics_rural_urban_counties. html. Accessed September 15, 2019.

5. Pennsylvania Department of Health. Hospital Reports. 2019; https://www. health.pa.gov/topics/HealthStatistics/HealthFacilities/HospitalReports/ Pages/hospital-reports.aspx. Accessed September 9, 2019.

6. Pennsylvania Health Care Cost Containment Council. Financial Analysis Fiscal Year 2016-2018. 2019; http://www.phc4.org/reports/fin/18/. Accessed September 9, 2019.

Publisher's Note: Springer Nature remains neutral with regard to jurisdictional claims in published maps and institutional affiliations. 